\title{
World Agenda on Sustainable Recovery from the Covid-19 Pandemic: Recover Together, Recover Stronger
}

\author{
Mohammed Ali Berawi ${ }^{1 *}$
}

${ }^{1}$ Faculty of Engineering, Universitas Indonesia, Kampus UI Depok, Depok 16424, Indonesia

For the first time, Indonesia will host the G20 Presidency in 2022 with the theme of "Recover Together, Recover Stronger", which reflects the spirit of collective global recovery needed after the world has struggled to deal with the Covid-19 pandemic since early 2020. The theme sets out the vision that no one is left behind and, with this collective recovery process, G20 must be present inclusively to promote and act on the spirit of a sustainable global recovery.

As a result of the pandemic, many governments require prompt actions in supporting their country's health and economic resilience, including conducting vaccination, protecting workers and businesses, and empowering the vulnerable through adequate social protection. Thus, an international commitment to ensure adequate financing to contain the pandemic and protect people, exchange clinical data, and share medical supplies and vaccines is important for strengthening global health systems. On the other hand, global solidarity on supporting economic resilience is conducted through enhancing fiscal and debt management capacity, fair investment support, and social protection to overcome the pandemic crisis.

\section{Future Global Agenda}

Global cooperation is required in order to fight the COVID-19 pandemic, to enhance an inclusive and sustainable economy recovery, and to protect and regenerate nature.

I would like to highlight some recommendations for G20 agenda discussion, particularly in the role of science and technology in sustainable development and a need to strengthen international collaboration and cooperation.

Science and technology development plays a significant role in achieving sustainable development by improving the efficiency and efficacy of new and more sustainable approaches to development. Investments in green technology, efficient and effective processes, safer materials, and improved performances and outcomes are some results of such development. Technological development in utilizing renewable energy resources, building urban water systems and sustainable public infrastructure, increasing food production, and producing environmentally friendly materials and products are among the pathways by which technology will significantly contribute to achieving sustainable development targets. 
Science and technology will assist us in tackling the pandemic by producing a suitable strategy for monitoring, treating, mitigating, and recovering from its impact. To anticipate such impact, a comprehensive plan is required for increasing the capacity for disruptions and surges in demand, especially for basic needs such as health and medicine, food, water, and energy. The COVID-19 pandemic suggests the need to rethink the role of resilience knowledge and practices in order to ensure the performance of the built environment to meet the health-related criteria.

Advancements in the science and technology revolution need to play a significant role in shaping and regenerating nature (Nature 5.0). The environmental changes have altered the evolution of life, and with the advancement of technology, changes have fed back to alter the environment. Thus, there is a need to utilize the industrial revolution 4.0 and society 5.0 towards nature 5.0 .

For international collaboration and cooperation, I would like to highlight a need to carefully manage the social, environmental, and economic dimensions of this crisis in order to enhance societies' and countries' resilience.

The Sustainable Development Goals (SDGs) established actions to end poverty, improve health and education, and promote prosperity and well-being by considering environmental sustainability, which requires value changes, institutional changes, and cultural adjustment.

Managing cross-sectoral interests with coordinated aims, strategies, and instruments is essential to overcoming complex problems and developing more comprehensive solutions in accelerating SDG programs. Creating a more integrative manner to enhance the effectiveness and efficiency of public policies is key for optimizing the benefits and impact of development outcomes. This policy integration and coordination is crucial to enhancing sustainable development programs, which balance economic advancement, sustainable ecosystem management, and environmental protection; therefore, it requires an inter-sector approach and coordinating mechanisms for all programs and projects.

Responses to COVID-19 have also prompted a strong drive to reduce inequal access to, and the quality of, public education and health facilities supported by government policies in order to increase the country's resilience. Furthermore, this drive will prompt stronger support for small and medium enterprises through business incubators and start-up companies to ensure urban economic resilience. The future development is a model with an emphasis on innovation, inclusivity, and sustainability. The world development agenda can be boosted by strengthened knowledge-sharing and collaboration amongst stakeholders in international contexts.

Therefore, G20 members need to commit to supporting the science and technology process and expanding access across countries members. G20 needs to strengthen cooperation in order to overcome the pandemic and enhance fiscal and debt management capacity towards science and technology development.

\section{Science and Technology Capacity Development}

Technology exists to improve projects, products, or services that perform for our benefits. In this edition, we are pleased to present twenty papers dedicated to technology development in science and engineering.

The first paper, written by K. Tarantseva, N. Politaeva, K. Tarantsev, M. Yakhkind, and A.K. Mishra, investigates the chemical resistance and catalytic activity of copper during the electrooxidation of ethanol in strong alkaline media. The authors argue that the inexpensive copper catalysts allow the fuel cells to be used as a power source for small portable devices or remote sensors. 
The next paper, written by E.F. Karamah, D.S. Arbi, I. Bagas, and S. Kartohardjono, evaluates the hollow fiber membrane modules' performance in the NOx absorption process using sodium chlorate $\left(\mathrm{NaClO}_{3}\right)$ and sodium hydroxide $(\mathrm{NaOH})$ together as an absorbent solution. The authors argue that NOx's absorption efficiency increased by increasing the $\mathrm{NaClO}_{3}$ concentration in the absorbent solution along with the amount of fibers in the membrane module.

The third paper, written by N.H. Thang, B.K. Thach, and D.Q. Minh, evaluates the influence of curing regimes on engineering and microstructural properties of geopolymerbased materials from water treatment residue and fly ash. The authors argue that the hydrothermal samples produce better properties of $\mathrm{pH}<9$, high stability of mechanical strength over $3.5 \mathrm{MPa}$, and soft coefficients over 0.75 .

The fourth paper, written by T.Y. Hwang, H.A. Qi, C.M. Kin, W.L. Shing, S. Djearamane, and $\mathrm{C}$. Thirunavukkarasu, explores the potential for using fruit peels as a culture medium for Anabaena cylindrica. The authors argue that $A$. cylindrica can produce its greatest biomass in a $20 \%$ papaya medium and possesses the highest growth rate in a $10 \%$ pineapple peel medium.

The fifth paper, written by N.F.A.C. Mohamad, N.S.N. Failei, N.M. Rased, A. Adnan, M.N. Ling, H.A. Zakeri, E. Kusrini, and F. Hashim, presents a method for determining the viability of acanthamoeba cysts. The authors argue that the method can be used to determine acanthamoeba cyst viability based on membrane integrity, fluorescence intensity, and absorbance.

The next paper, written by I.W.K Suryawan, I.Y. Septiariva, Q. Helmy, S. Notodarmojo, M. Wulandari, N.K. Sari, A. Sarwono, R. Pratiwi, and J.W. Lim, investigates the comparison of ozone pre-treatment and post-treatment hybrids with a moving bed biofilm reactor in the removal of remazol black 5. The authors argue that the effluent treatment shows the highest COD and color removal results of $76.8 \%$ and $99 \%$, respectively.

The seventh paper, written by O. Muktaridha, M. Adlim, Suhendrayatna, Ismail, and N.H.H. Abu-Bakar, examines the photocatalytic degradation of skim-latex-vapor odor using iron-doped zinc oxide. The authors argue that gas chromatography-mass spectroscopy detected 24 dominant chemical components in the VOC-NR stock before photocatalytic degradation.

The eighth paper, written by Y.I. Supriyatna, W. Astuti, S. Sumardi, Sudibyo, A. Prasetya, L.I.B. Ginting, Y. Irmawati, N.S. Asri, and H.T.B.M Petrus, investigates the correlation of nano titanium dioxide synthesis and the mineralogical characterization of ilmenite ore as raw material. The authors argue that roasting with caustic soda shows a better nano titanium dioxide purity with $96.04 \%$ of $\mathrm{TiO}_{2}$ and particle size in the range of 50-80 nanometers.

The next paper, written by N. Suriaini, N. Arpi, Y. Syamsuddin, and M.D. Supardan, examines the use of crude glycerol for glycerolysis of free fatty acids in crude palm oil. The authors argue that the crude glycerol as a side product of transesterification can be utilized in glycerolysis to lower the cost of biodiesel production.

The tenth paper, written by T. Istirokhatun, H. Susanto, M.A. Budihardjo, E. Septiyani, A.R. Wibowo, and E.F Karamah, explores the treatment for batik industry wastewater plant effluent using nanofiltration. The authors argue that the concentration polarization contributes significantly to the flux decline but fouling via gel or cake layer formation still dominates the cause of the flux decline.

The eleventh paper, written by J. Rahman, Y. Shoukaku, and T. Iwai, examines the effect of load and moving speed on free rotating rubber contact using fluorescence microscopy. The authors argue that, on moving-speed influence, the trend line of rubber 
contact increases at a lower speed, reaching the highest value at a moving speed of 8 $\mathrm{mm} / \mathrm{s}$, and decreases as the moving speed increases further.

The next paper, written by S. Samsudin, N.A. Aziz, A.A. Hairuddin, and S.U. Masuri, investigates sub-bituminous coal sintering ratio for predicting coal ash slagging factors. The authors argue that there are minimal ash deposition tendencies for sub-bituminous coal ash with a low sinter ratio of 0.2 , whereas the ash deposition tendencies are high for high sinter ratios of 0.8 and above.

The thirteenth paper, written by A.A. Nugraha, D.A. Sumarsono, M. Adhitya, and S. Prasetya, presents a brake booster design for an electric city car MEV-02 with a maximum vehicle weight of $1.286 \mathrm{~kg}$ and a maximum vehicle speed of $80 \mathrm{~km} / \mathrm{hour}$. The authors argue that the electric brake boosters can reduce electricity consumption by $28.2 \%$.

The fourteenth paper, written by A. Wibawa, D. Ichsani, and M.N. Yuniarto, examines the life cycle analysis to determine optimum operation and maintenance strategies for a power plant. The authors argue that, by combining three factors (reliability, efficiency, and capacity), they can provide the best decision for all aspects of the power plant, such as operation maintenance, cost, and revenue.

The next paper, written by M.L. Hakim, B. Nugroho, I.K. Suastika, and I.K.A.P. Utama, presents an alternative empirical formula for predicting the frictional drag penalty due to fouling on the ship hull using the design of experiments (DoE) method. The authors argue that the alternative formula is suitable as an initial tool for determining the impact fouling on ship performance.

The sixteenth paper, written by M.A. Heryanto and B. Kusumoputro, investigates the attitude and altitude control of quadcopter maneuvers using neural network-based direct inverse control (DIC). The authors argue that the neural network-based DIC could follow the maneuvers of the testing trajectory dataset with excellent performance.

The next paper, written by A. Rusdinar, I. Purnama, A.Z. Fuadi, H. Adiluhung, M. Wicaksono, Risnanda, and R.A. Ningrum, presents an Automated UVC Light Mobile Robot (AUMR) for room sterilization and disinfection. The authors argue that the AUMR can reduce and kill airborne bacteria; therefore, it can disinfect different types of rooms (e.g., isolation, operating, and public rooms) contaminated with hazardous bacteria, such as COVID-19.

The eighteenth paper, written by C. Sitompul and O.M. Horas, investigates a vehicle routing problem with time windows subject to the constraint of vehicles' and goods' dimensions. The authors argue that the model can be used to increase the capacity utilization of vehicle containers and reduce the total travel distance.

The nineteenth paper, written by B. Wirjodirdjo, A.G. Budianto, A. Widjanarka, I.N. Pujawan, and I. Maflahah, examines forwarders' strategies to utilize the immobile shipping capacity of freight forwarders (FF) and maximize profits. The authors argue that profits can be increased due to the optimization of capacity sharing performance.

The last paper, written by T. Mustikawati, Y.A. Yatmo, and P. Atmodiwirjo, examines tours' and maps' operations as a movement mechanism in indoor wayfinding. The authors argue that understanding movement mechanisms by exploring operations in a wayfinding journey could contribute to the development of digital navigation systems for indoor wayfinding. 
I hope that this edition of IJTech conveys some new insights in the way we conduct our research. I am pleased to accept and respond to any comment or enquiry you may have on the direction and content of IJTech, and I invite you to join us in this venture by sending your work for consideration.

With warmest regards from Jakarta,

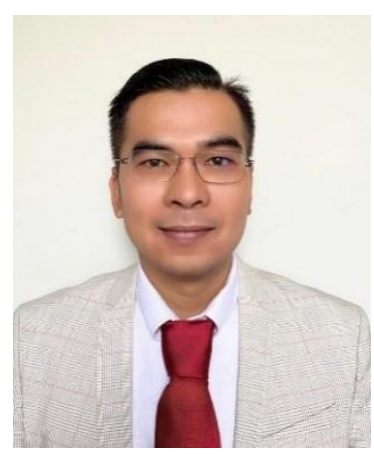

Dr. Mohammed Ali Berawi Editor in Chief 